推光花スポツトの魅力度を考虑した

観光行動分析と入込及客数の了則

STUDY ON THE RECREATION ACTIVITY BY RECREATION SPOT ATTRACTIVE INDEX

高橋 清* 五十嵐 日出夫**

B y Kiyoshi TAKAHASHI, Hideo IGARASHI

\begin{abstract}
This paper proposes a model which is able to forcast the volume of recreation trip distribution, and the impactson them of any associated projects such as new development of recreation points.

The analysis of the recreation trip were mainly achieved through the huff model by using recreation potential. We calculate values of the weight for each factor which consists of the recreation potential by AHP. Analytic Hierarchy Process (AHP) introduced to this paper was advocated by Saaty in 1971 as the decision making theory of uncertain state or various criterion evaluation. Using the Hakodate Urban Area Data obtained by the original our survey, the calibration caused good results.
\end{abstract}

1.はじめに

我が国では、近年における個人の可処分所得と余 㗇時間の増加に伴い、観光・レクリエーション需要 が飛躍的に増大してきた。これを受け各地の観光都 市には観光客が溢れ、都市内交通の混雑が助長され て、今やそれへの対策が交通計画上の緊急な課題に なっている。

ところでミクロ的に観光交通を分析するには、観 光スポットの魅力度とそれに誘引される観光客の流 動が重要となる。しかし、観光スポットの魅力度の 計測は、魅力度を構成する要素が多数存在し、数量 的に表現しにくい質的な要素が多く含まれることも あって、容易ではない。

著者らは、かねてから観光スポットが保持する固 有な魅力度を、その観光スポットにおける入込み人

* 学生員 工修 北海道大学大学院 工学部 土木 工学科 ( $=060$ 札幌市北区北 13 条西 8丁目)

** 正員 工博 北海道大学教授 工学部 土木工学科
数と滞在時間の積であると考え研究を進めてきた。 しかし、入込み人数をその観光スポットの魅力度指 標として用いるならば、新規に開発したり、改良し た観光スポットについての魅力度を知るために、あ らかじめ入込み人数を予測する必要がある。ここで 入込み人数の予測は、まず観光スポットへのアクセ ス距離等による制約条件を括て去った観光スポット が保持する観光的資質 (以下ポテンシャルという) を求め、そのポテンシャルを用いたモデルにより、 スポット間の旅客流動を推定すればよいことになる。

もしまた、観光スポットのポテンシャルが別途推 計できるならば、そこへの入込み客数の予測も可能 になるのである。

そこで本研究では、観光スポットの魅力度を構成 する要因の一つと考えられる、入込み人数の予測を 行う。入込み人数を予測する際、特に観光スポット の持つポテンシャルに注目し、A H P 手法によりポ テンシャルの計測を行い、このポテンシャルを用い 
たハフモテルによるスポット間流動を分析する。

以上より、スポット間流動のミクロ的な観光動態 調査とともに、観光スポットの魅力度を考虑した観 光交通計画の一手法を提案しようとするものである。

\section{2. 観光スポット選択モデル}

\section{（1）観光交通モデルの流れ ${ }^{11}$}

観光交通分析に関して、田村、千葉、大炭らは観 光交通需要分析の観点より既存研究のまとめを行っ ている。2) また、観光交通のミクロ分析について は、発生交通量予測において、1970年代中ごろ より数量化理論による展開が行われている。しかし、 明確に行動理論的アプローチに基づいた研究は、ま だ十分になされているとはいえない。

海外においては、発生交通分析や活動分析に、パ ーソナリティ、評価值、ライフスタイル、ライフサ イクル等を考慮した多変量解析や非集計モデルの適 用がみられる。また分布交通に対しては、最近ミク ロレベルの分析が行われるようになった。しかし依 然として主流は、集計型のマクロ分析であり、特に オポチュニティモテルの使用が目立っている。る

また、観光周遊交通における田村の研究や、溝上 らの研究は興味深い。以上は、観光スポットに注目 した、観光ルート選択モデルに関する研究である。 しかし、これらもテータの集計上等の問題が残され ている。11,4

\section{（2）観光スポット選択モデル}

観光スポットの入込み人数を推計することは、観 光交通計画の視点からみるならば、観光スポット選 択モテルに基づいた、スポット間の分布交通量を求 めることであるとも考えられる。

さて、観光スポット選択行動を観察すると、行動 の動機や、目的地選択などの行動メカニズムは、買 物交通ときわめて類似しているといえる。そこで、 買物交通行動の分析に用いられている消費者行動理 論の考え方に基づいて、観光スポット選択行動をモ デル化することを試みる。

一般に消費者行動理論として用いられているもの は、(1)主として消費者の選択対象である商品やサー ビスの効用值を測定しようとするもの（コンジョイ
ント分析として知られる）、(2個人及び集団の選択 行動の時系列・横断的予測を主な目的とするもの（ 確率的選択行動モデルを用いた分析）等が代表的で ある。ここで取り上げるのはこの内の確率的選択行 動モデルによる分析であり、定数効用モテルとして 広く知られているハフモデル (huff model) による 方法である。

ハフモデルとは、L u c e の「個人選択公理」に 基づくものであり、次のように表現される。

ある選択状況（時点、場所）下において、個人か $\mathrm{n}$ 個の対象のうちの 1 つを選ぶ確率Prob. (X,C) は 次式で表わすことができる。

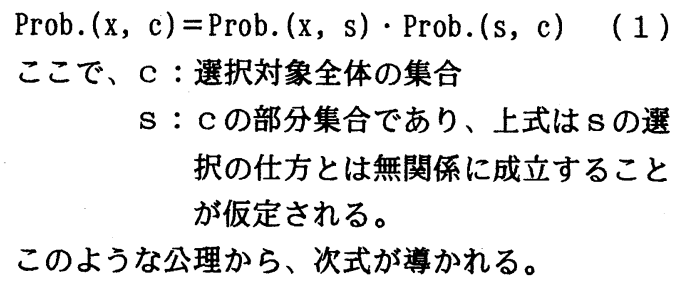
択の仕方とは無関係に成立すること が仮定される。

このような公理から、次式が導かれる。

Prob. (J, c) $=U j / \sum_{n \in C} U r$

以上のことを観光行動に当てはめると、観光行動 は「観光客が観光スポットを選択する際には、選択 する観光スポットのポテンシャルと距離を考虑して 意思決定を行うものとする。」と考えられる。

上の仮定を満足する、ハフモテルによる観光スポ ット選択モデルは、式ー3、式ー4に示すように定 式化できる。

$$
\begin{aligned}
& U_{i j}=\frac{P_{i j}^{\alpha}}{R^{\beta}{ }_{i j}} \cdots \\
& U i j=i \text { から } j \text { に行くことの効用 } \\
& R i j=i \text { 地点と } j \text { 地点の時間距離（分） } \\
& \mathrm{P} i \mathrm{j}=\mathrm{i} \text { 地点からみた } \mathrm{j} \text { 地点のポテンシャル } \\
& \alpha, \beta=\text { パラメータ } \\
& T_{i j}=\frac{U_{i j}}{\sum_{j=1}^{n} U_{i j}} \cdots
\end{aligned}
$$

ハフモデルの適用により、観光スポット選択行動 が明かとなり、また、データ制約を受ける観光行動 
分析に対しデータを集計しモデルを構築することが 可能となる。

しかし、以上のモテル構築に関する問題点は、観 光スポットのポテンシャルをいかに定量化するかと いう問題である。この観光スポットのポテンシャル 計測方法はこれまでにも数多く提案されているが、 ポテンシャルがどちらかといえば定性的要因で構成 されていると考えられるため、定量的に計測するこ とは容易ではない。

\section{（3）観光スポットのポテンシャル計測}

本研究では観光スポットのポテンシャル計測に際 し、AHP (Analytic Hierarchy Process) 手法を 適用する。

A H P 手法は従来、複雑な状況下での意思決定を 行うための意思決定手法の一つであるが、本研究で は、以下のような特長をいかし観光スポットのポテ ンシャル計測に適用する。5)，(2)，71，31

A H P 手法の特長は、要因を階層化するため観光 スポットのポテンシャルを構造的に把握できること である。また、一対比較を用いることで定性的な要 因も容易に評価でき、さらに新規のポテンシャルを 予測する場合、階層化された要因毎に既存のものと の一対比較により判断を行うため、評価基準が明確 となりより正確な予測が行なえるといった特長を有 する。

3. アクティビティを考虑した観光パーソントリッ プ調查

\section{（1）観光パーソントリップ調査の意義}

前述のようにハフモデルの構築に際し、観光ポテ ンシャルの定量化とともに問題となるのが、ミクロ 的な観光スポット間のODデータの収集である。特 に観光交通は、非日常的交通であり、周遊性や変動 が多種にわたるため、日常交通に比較し分析上困難 な点が多い。また、従来のような大規模なパーソン トリップ調査のデータでは、大まかすぎて観光スポ ット間における交通の現状を把握することは困難で ある。9),10111),121

それゆえ、都市内観光交通に注目する場合にはき めの細かな観光交通実態調查を行う必要性がある。
特に観光交通においては、観光スポット間のODと いったような通常のO Dデータよりきめの細かいデ 一夕を得る必要がある。また、観光交通は観光行動 の一部分と考えられるため、一連の活動の流れを表 現するようなデータが必要となる。これはすなわち、 アクティビテイ分析の一種であって、滞在時間や時 刻制約を表現できるため、刻々と変化する観光交通 の実態調查を知るためにきわめて重要である。

\section{（2）函館市観光パーソントリップ調查の概要}

このような目的のため、アクティビティ・ベイス ト・アプローチを用いて、昭和 62 年 8 月北海道函館 市において観光パーソントリップ調査を行った。

調査内容は大きく 1 ) 観光流動調查、2）観光 スポット入込み人数調查、3) 観光客举動調查 の 3 種類に分けることが出来る。

1）の調査では観光スポット間のODを、2）の 調查では観光スポットの入込み人数を、3) では観 光客個人個人の各時刻毎のアクティビティ（活動） をきめ細かく知ることが出来る。今回は観光流動調 查及び観光客挙動調査から、それぞれ 3656 票、 241 票の有効回収票が得られた。

\section{A H P 手法による観光ポテンシャル計測}

\section{(1) A H P の数学的背景}

各層のあるレべルの要素 $\mathrm{A}_{1}, \mathrm{~A}_{2}, \cdot \mathrm{A}_{n}$ のすぐ上 のレベルの要素に対する重み $\mathrm{W}_{1}, \mathrm{~W}_{2}, \cdot \mathrm{W}_{\mathrm{n}}$ を求め たい。このとき、 $a_{i}$ の $a_{j}$ に対する重要度を $a_{i j}$ と すれば、要素 $\mathrm{A}_{1}, \cdots \mathrm{A}_{n}$ の一対比較マトリックス は $A=\left[a_{i j}\right]$ となる。もし $W_{1}, \cdots W_{n}$ が既知の 時、 $A=\left[a_{i j}\right]$ は次のようになる。

$$
\begin{aligned}
& \begin{array}{llll}
\mathrm{A}_{1} & \mathrm{~A}_{2} & \cdots & \mathrm{A}_{n}
\end{array} \\
& A=\left[a_{i j}\right]=\begin{array}{c}
A_{1} \\
A 2 \\
\cdot \\
A_{n}
\end{array}\left(\begin{array}{cccc}
W_{1} / W_{1} & W_{1} / W_{2} & \cdots & W_{1} / W_{n} \\
W_{2} / W_{1} & W_{2} / W_{2} & \cdots & W_{2} / W_{n} \\
\cdot & \cdot & \cdot \\
\cdot & \cdot & \cdot \\
W_{n} / W_{1} & W_{n} / W_{2} & \cdots & W_{n} / W_{n}
\end{array}\right)
\end{aligned}
$$

ただし、 
$a_{i j}=W_{i} / W_{j}, \quad a_{j i}=1 / a_{i j} \quad W=\left(\begin{array}{c}W_{1} \\ W_{2} \\ \cdot \\ \cdot \\ W_{n}\end{array}\right)$ ところで、全ての場合の $i, j, k$,$k い て a_{i j} x$ $a_{j k}=a_{i k}$ が成り立つ。これは意思決定者の判断が 完全に首尾一貫していることを意味する。さて、こ の一対比較マトリックス $\mathrm{A}$ に重み列ベクトルWを掛 けると、ベクトル $\mathrm{n} \cdot \mathrm{W}$ を得る。すなわち

$\mathrm{A} \cdot \mathrm{W}=\mathrm{n} \cdot \mathrm{W}$

となる。この式は、固有値問題

$$
(\mathrm{A}-\mathrm{n} \cdot \mathrm{I}) \cdot \mathrm{W}=\mathrm{O}
$$

に変形できる。ここで、W=0が成り立つためには $\mathrm{n}$ がAの固有值にならなければならない。このとき WはAの固有べクトルとなる。さらにAのランクは 1 であるから、固有值 $\lambda_{i}(i=1, \cdots, n)$ は一つ だけが非零で他は零となる。また、Aの主対角要素 の和はnであるから、だだ一つ零でない入 $\mathrm{i}$ え $\lambda \max$ とすると、

$$
\lambda_{i}=0, \quad \lambda \max =n \quad\left(\lambda_{i} \neq \lambda \max \right)
$$

となる。したがって $\mathrm{A}_{1}$ ，・・Anに対する重みべク トルWは $\mathrm{A}$ の最大固有值入 maxに対する正規化した $\left(\Sigma W_{i}=1\right)$ 固有ベクトルとなる。

さて、実際に複雑な状況下の問題を解決するとき はWが未知であり、W'を求めなければならない。 したがって上述したようにW' は意思決定者の答え から得られた一対比較マトリックスより計算する。 このような問題は、

$\mathrm{A}^{\prime} \mathrm{W}^{\prime}=\lambda^{\prime} \max \mathrm{W}^{\prime}$

\section{（ $\lambda^{\prime} \max$ は $A^{\prime}$ の最大固有値）} となる。したがって、上述したようにW' は $\mathrm{A}^{\prime}$ の 最大 $\lambda{ }^{\prime} \max$ に対する正規化した固有べクトルとなる。 これにより末知の $\mathrm{W}^{\prime}$ が求まる。

ところで実際に状況が複雑になればなるほど意思 決定者の答えが整合しなくなる（首尾一貫しなくな る）。このようにA’ が整合しなくなるにつれて必

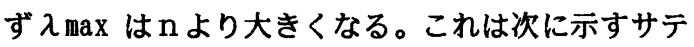
イの定理により明かである。つまり、

$$
\lambda \max =n+
$$

より常に $\lambda \max \geqq n$ が成り立ち、等号は首尾一貫性 の条件が満たされたときのみ成立する。これから、 首尾一貫性の尺度として

$C I=\frac{\lambda \max -n}{n-1}$

をコンシステンシー指数とする。たとえば C I = 0 は完全に首尾一貫性があるという意味である。また、 C I $\leqq 0 １$ を有効性の限界とする。

(2) ポテンシャル計測プロセス

1) 第 1 段階（問題の構造化）

複雑な状況下にある問題を階層構造に分解する。 ただし、階層の最上層は、1 個の要素からなる総合 目的である。それ以下のレベルでは意思決定者の主 観的判断により、一つのレベルがいくつかの要素に より構成されている。最後に、階層の最下層に代替 案をおく。

本研究では、最上層の総合目的は、観光スポット のポテンシャルである。以下評価基準となる、観光 スポットのポテンシャルを規定する要因を決定する ために、まずブレーンストーミングを行ない観光ス ポットへ行きたい理由を抽出、列挙を行った。つぎ に構造化手法の一つである、F S M (Fuzzy Structural Modeling) 手法により構造化を行い、ポテン シャルを評価するする要因として以下の 4 要因を決 定した。

1) 有名である

2) 雾囲気・イメージがよい

3) 詈観がよい

4) 観光サービス施設がよい

今回は、評価要因のレベルを1層として、階層困 を構成することとする。

最下層におく代替案は分析対象の観光スポットと とし、図ー 1 に示す函館市における入込み人数の多 い観光スポットとし以下の5つを選定した。

1) 五稜郭

2) トラピスチヌ修道院

3 ) 函館山

4) 西部地区

5 ) 駅前 - 朝市 


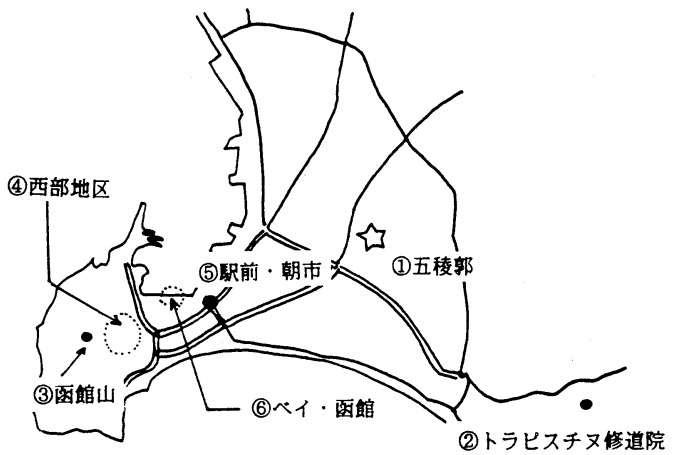

図-1 函館市内観光分布図

以上により構築されたA H Pによる意思決定階層 困を図ー2に示す。

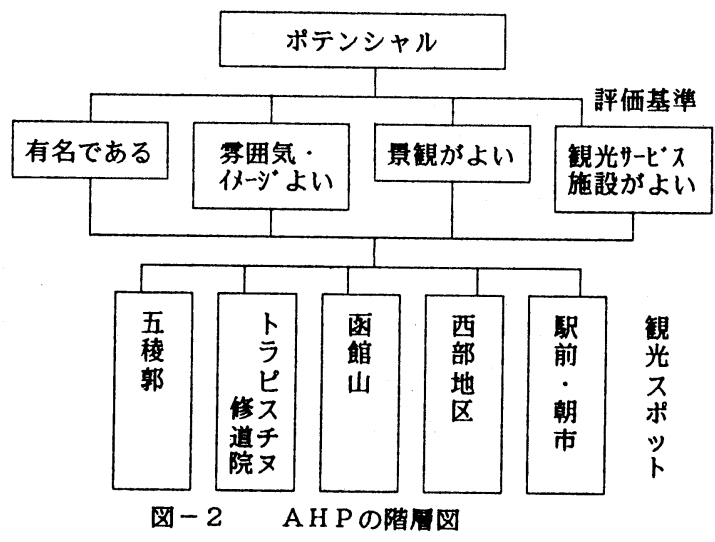

2 ）第 2 段階（要因の比較）

各レベルの要因間の重み付けを行う。つまり、あ る一つのレベルにおける要因間の一対比較を一つ上 のレベルにある関係要素を評価基準として行う。

以上のようにして得られた各レベルの一対比較マ トリックスから、各レベルの要因間の重みを算出す る。この一対比較において、意思決定者の首尾一貫 した回答の指数として、コンシステンシー指数 ( C I ）を定義する。

3) 第 3 段階（代替案の重みの決定）

各レベルの要因間の重みが算出されると、この結 果を用いて階層全体の重みの計算を行う。これによ り、総合目的に対する各代替案の重み、本研究では 観光スポットのポテンシャルが計測される。

（３）AH P 手法によるポテンシャル計測

評価基準間および観光スポット間の重みを算出す るため、平成 2 年 1 月 26 日, 27 日，28日函館市にお
いて A H P の一対比較部分を含む観光行動アンケー トを実施した。アンケート方法は、ヒリャリング方 式により、46票の回収票を得た。被験者の属性は、 男性 $52.2 \%$ 、女性 $47.8 \%$ であり、20才代が $54.3 \%$ を 占めている。また、道外からの観光客が $78.3 \%$ と約 8 割であった。以下がアンケート票の一対比較部分 の一例である。(図ー3)

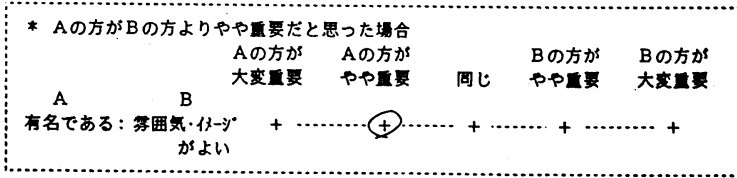

$$
\text { 図ー3 一対比較アンケートの一例 }
$$

このアンケート結果を用いて算出した評価基準間 の重みを表ー 1 に、観光スポットの各評価基準に対 する重みと総合的な重みを表 - 2 に示す。今回、各 重みを集計する方法として、各アンケート票におけ るC．Ｉ．を計算し 0.1 をこえる回答を棄却し、採 択された回答について幾何平均により集計を行った。

表 -1 評価基準間の重み

\begin{tabular}{|c|c|c|c|c|}
\hline 要因 & $\begin{array}{l}\text { 有名 } \\
\text { である }\end{array}$ & $\begin{array}{c}\text { 每囲気 } \\
\text { がよい }\end{array}$ & $\begin{array}{l}\text { 景観 } \\
\text { がよい }\end{array}$ & $\begin{array}{l}\text { サービス } \\
\text { がよい }\end{array}$ \\
\hline 重み付け & 0.167 & 0.334 & 0.367 & 0.133 \\
\hline
\end{tabular}

表ー2 各評価基準に対する重みと縔合的な重み

\begin{tabular}{|c|c|c|c|c|c|}
\hline $\begin{array}{c}\text { 钼光スボ } \\
\text { ット名 }\end{array}$ & 五稜郭 & $\begin{array}{l}\text { 卜北梀 } \\
\text { 渗道院 }\end{array}$ & 函館山 & $\begin{array}{c}\text { 西部 } \\
\text { 地区 }\end{array}$ & $\begin{array}{r}\text { 駅前. } \\
\text { 朝市 }\end{array}$ \\
\hline 有名 & 0.196 & 0.123 & 0.370 & 0.152 & 0.158 \\
\hline 雾囲気 & 0.101 & 0.176 & 0.403 & 0.195 & 0.124 \\
\hline 景钼 & 0.146 & 0.186 & 0.436 & 0.163 & 0.069 \\
\hline サーピス & 0.156 & 0.134 & 0.435 & 0.160 & 0.113 \\
\hline 絡合重み & 0.141 & 0.165 & 0.414 & 0.172 & 0.108 \\
\hline
\end{tabular}

この重みは観光スポットを訪ねたいという意欲識 の度合であり、観光行動における距離抵抗となる時 間や予算等の制約条件が入っていない観光スポット 本来の固有の資覧（ポテンシャル）を表わしている と考えられる。 


\section{5. 観光スポット入込人数予測}

\section{（1）観光スポット選択モデルの構筑}

A H P 手法により各観光スポットの相対的ポテン シャルの計測が可能となった。この值をポテンシャ ルとして用い、式ー1のパラメータ推定を行う。距 離抵抗として用いた数值は、表一 3 に示されるよう に、大量輸送機関と個別輸送機関の重み付けによる 平均時間距離（分）を用いた。

\begin{tabular}{|c|c|c|c|c|c|}
\hline \multirow[t]{2}{*}{ 表 -3} & 7 & & !䀦 & \multicolumn{2}{|c|}{ 単位（分） } \\
\hline & 五稜郭 & $\begin{array}{l}\text { 扎双平 } \\
\text { 俈道院 }\end{array}$ & 函館山 & $\begin{array}{l}\text { 西部 } \\
\text { 地区 }\end{array}$ & $\begin{array}{l}\text { 駅前. } \\
\text { 朝市 }\end{array}$ \\
\hline 五＼cjkstart稜＼cjkstart郭 & - & 27.4 & 26.7 & 28.6 & 16.3 \\
\hline ト比胒子难道院 & 27.4 & - & 48.9 & 48.6 & 38.4 \\
\hline 函 館 山 & 26.7 & 48.9 & - & 5.3 & 10.5 \\
\hline 西部地区 & 28.6 & 48.6 & 5.3 & - & 11.6 \\
\hline 駅前 - 朝市 & 16.3 & 38.4 & 10.5 & 11.6 & - \\
\hline
\end{tabular}

パラメー夕推定にあたっては、前述した、昭和 62 年度函館パーソントリップ調査における観光スポッ 卜間分布交通量の $\mathrm{D}$ 值を用いた。(表一 4 )

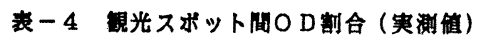

\begin{tabular}{|c|c|c|c|c|c|}
\hline & 五稜郭 & $\begin{array}{l}\text { 我不平 } \\
\text { 信道院 }\end{array}$ & 函館山 & $\begin{array}{c}\text { 西部 } \\
\text { 地区 }\end{array}$ & $\begin{array}{l}\text { 駅前. } \\
\text { 朝市 }\end{array}$ \\
\hline 五 稜 郭 & - & 0.300 & 0.419 & 0.158 & 0.123 \\
\hline 卜北只不难道院 & 0.321 & - & 0.429 & 0.139 & 0.111 \\
\hline 画 剆 山 & 0.136 & 0.081 & - & 0.329 & 0.453 \\
\hline 西部地区 & 0.072 & 0.048 & 0.757 & - & 0.125 \\
\hline 略前・朝市 & 0.150 & 0.052 & 0.588 & 0.210 & - \\
\hline
\end{tabular}

以上より、ハフモデルを構築すると以下のように なる。 $\begin{aligned} U_{i j} & =\frac{P^{0.89_{i j}}}{R^{\nabla .5 \theta_{i j}}} \cdot \cdots \\ T_{i j} & =\frac{U_{i j}}{\sum_{j=1}^{n} U_{i j}} \cdots\end{aligned}$

式（5），（6）を用いて、各観光スポット間の 選択確率分布を求めたものが、表一 5 である。

（2）入込み人数の推定と魅力度

観光開始地点を函館駅前として、5．（1）で求 めた観光スポット選択確率を用いて各観光スポット の入込み人数の推定を行う。

\section{表ー5 锶光スポット間の遭択率分布}

\begin{tabular}{|c|c|c|c|c|c|}
\hline & 五稜䡉 & $\begin{array}{l}1 \text { 甩不平 } \\
\text { 偆道院 } \\
\end{array}$ & 函館山 & $\begin{array}{c}\text { 西部 } \\
\text { 地区 }\end{array}$ & $\begin{array}{c}\text { 駅前- } \\
\text { 朝市 }\end{array}$ \\
\hline 五 稜 部 & - & 0.185 & 0.453 & 0.198 & 0.184 \\
\hline 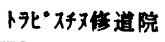 & 0.230 & - & 0.427 & 0.195 & 0.148 \\
\hline 函 館 山 & 0.158 & 0.128 & - & 0.497 & 0.217 \\
\hline 西部地区 & 0.096 & 0.081 & 0.692 & - & 0.131 \\
\hline 駅前 - 朝市 & 0.105 & 0.072 & 0.357 & 0.154 & - \\
\hline
\end{tabular}

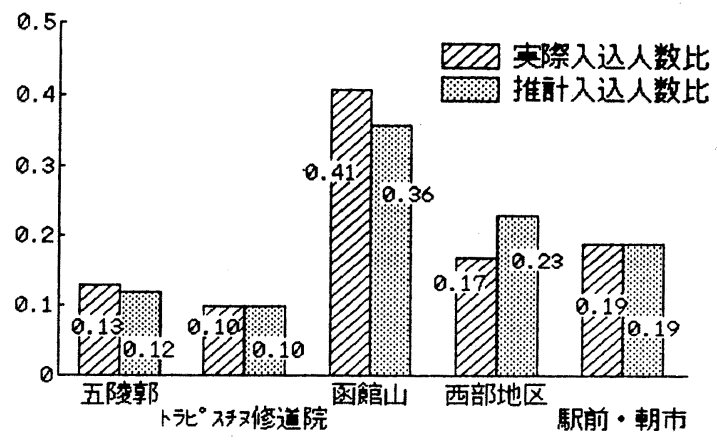

図-4 観光スポット入込み人数比 表一 5 の選択確率を基にトリップ数別人数比を用 い、各観光スポットの入込み人数を推計する。トリ ップ数別人数比は観光パーソントリップ調査による と自家用車などの個別輸送機関利用者は、平均 4.7 地点の周遊地点を、また電車などの大量交通機関利 用者は3.7 地点を周遊していることがわかっている。

算出した計算入込み人数比と昭和 62 年度実際入込 み人数比を比較した結果を図ー4に示す。

計算入込み人数比と昭和 62 年度実際入込み人数比 はよく合致している。この結果より観光交通におい て本研究のモデルが、観光行動をうまく表わし、入 込み人数の推計に至るまでの分析として、非常に有 用であることが明かとなった。

（3）新規観光スポットの入込み人数の予測 入込み人数の将来予測に本研究で提案された方法 を適用した場合の利点は次のように考えられる。

1 ) 定性的な要因で構成されているポテンシャル を、定量的にあつかうことができる。

2) ポテンシャルを構成している、要因が階層化 されているため一対比較が容易であり、新規観光ス 
ポットを既存の観光スポットと比較することにより、 より計画的な判断が出来る。

すなわち、本研究のモデルを用いることにより、 今までは困難であった新規観光スポットのポテンシ ヤルが計測され、入込み人数の推計が可能となる。

例えば、新規な観光スポットが出来たということ は、図一 5 に示すように最下層の代替案が 1 つ増加 したということになる。そして、この図より新規観 光スポットのポテンシャルは、既存の観光スポット との比較によって、予測出来る。その際、スポット の評価項目は変化しないと仮定する。

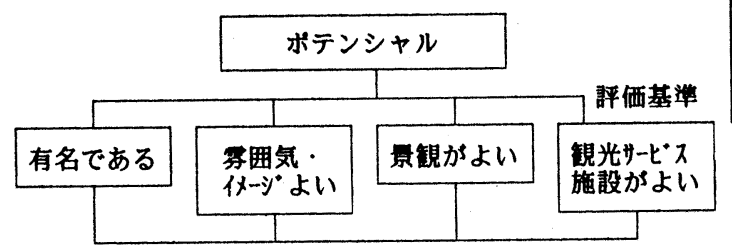

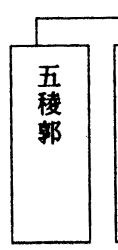

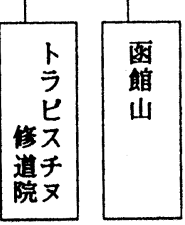

困 5

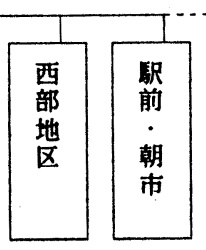

A H P の階同図

（新規钼光スポットを含む）
ところで今回は、新規観光スポットとして、函館 市において最近特に注目されている、ウォーターフ ロント開発のベイ函館を取り上げた。そして、本研 究で提案した方法により新規観光スポットのベイ函 館を含め、前述のアンケート調查の被者に対し一対 比較によるアンケートを行った。その際のポテンシ ヤルを表ー6に示す。

\section{表ー6 新規観光スボットを含む結合重み}

\begin{tabular}{|l|l|l|l|l|l|}
\hline 五稜郭 & $\begin{array}{l}\text { ト示㑈又 } \\
\text { 修道院 }\end{array}$ & 函館山 & $\begin{array}{c}\text { 西部 } \\
\text { 地区 }\end{array}$ & $\begin{array}{c}\text { 駅前・ } \\
\text { 朝市 }\end{array}$ & $\begin{array}{c}\text { ベイ } \\
\text { 函館 }\end{array}$ \\
\hline 0.120 & 0.140 & 0.351 & 0.145 & 0.092 & 0.151 \\
\hline
\end{tabular}

また、距離抵抗として用いた数值は、表ー7に示 すように、大量輸送機関と個別輸送機関の重み付け による平均時間距離（分）である。
さらにモデルのパラメーターは経年変化せず一定 であるとして、新規観光スポットのポテンシャルと 距蝔抵抗値を式（5），（6）に代入する。これに より計算された各観光スポットの選択率は表ー8に 示すとおりである。

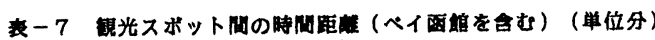

\begin{tabular}{|c|c|c|c|c|c|c|}
\hline & 五稜部 & $\begin{array}{l}\text { F北戏 } \\
\text { 敒道院 }\end{array}$ & 画饂山 & $\begin{array}{c}\text { 西部 } \\
\text { 地区 }\end{array}$ & 蚇前- & ベイ \\
\hline 五 稜 郭 & - & 27.4 & 26.7 & 28.6 & 16.3 & 26.0 \\
\hline 䚹”不双倍道院 & 27.4 & - & 48.8 & 48.8 & 38.4 & 46.7 \\
\hline 画 館 山 & 26.7 & 48.9 & - & 5.3 & 10.5 & 4.5 \\
\hline 西部地区 & 28.6 & 48.6 & 5.3 & - & 11.6 & 9.7 \\
\hline 駅前·朝市 & 16.3 & 38.4 & 10.5 & 11.61 & - & 4.5 \\
\hline ベイ函館 & 26.0 & 46.7 & 4.5 & 9.7 & 4.5 & - \\
\hline
\end{tabular}

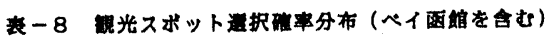

\begin{tabular}{|c|c|c|c|c|c|c|}
\hline & 五䅗部 & 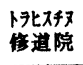 & 函勗山 & $\begin{array}{l}\text { 西部 } \\
\text { 地区 }\end{array}$ & $\begin{array}{c}\text { 毁前. } \\
\text { 朝市 }\end{array}$ & ベイ \\
\hline 五 稜 郭 & - & 0.157 & 0.363 & 0.158 & 0.149 & 0.173 \\
\hline ト北・不难道院 & 0.192 & - & 0.353 & 0.161 & 0.123 & 0.171 \\
\hline 画 蛛 山 & 0.102 & 0.081 & - & 0.316 & 0.139 & 0.362 \\
\hline 西部地区 & 0.079 & 0.066 & 0.563 & - & 0.107 & 0.185 \\
\hline 駅前- 朝市 & 0.082 & 0.057 & 0.279 & 0.1201 & - & 0.219 \\
\hline ヘイ函饂 & 0.073 & 0.058 & 0.548 & 0.157 & 0.165 & - \\
\hline
\end{tabular}

これらを用いて推計された新規観光スポットを含 む各観光スポットの入込み人数比を図ー6に示す。 これより、ベイ函館の入込み人数は他の観光スポッ 卜比較し、函館山に次ぎ多くなることが明かとなっ た。

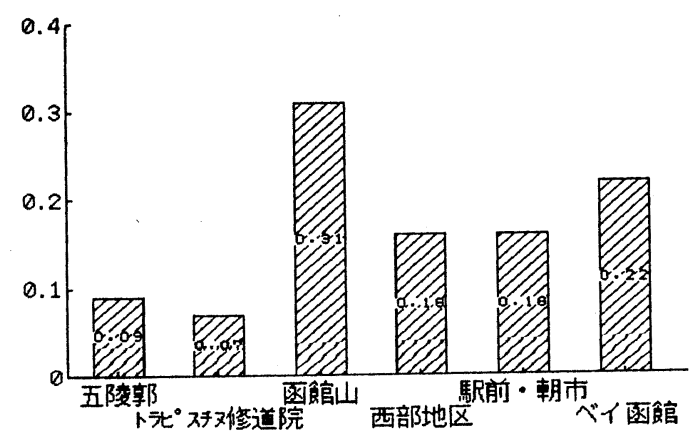

図-6 観光スポット入込み人数比推計值 
6. おわりに

本研究の成果は以下のようにまとめられる。

観光地の魅力度は観光スポット入込み人数と、滞 在時間をにより構成される。そのうち、入込み人数 を予測する場合、ハフモデルにより観光スポット選 択モデルを構築し、入込人数の推定を行うことは、 有効な方法である。しかし、ハフモデル構築にあた り、観光スポットのポテンシャルの定量化が必要と なる。

そこで本研究では、観光スポットのポテンシャル 計測にA H P 手法を用いその有用性を検証した。ま た、都市内観光交通の分析を行うには、ミクロ的な 観光交通データの収集が不可欠である。すなわち、 観光客のアクティビティを考虑した観光交通データ が必要である。そしてそれらが得られれば、本研究 において提案された新しい方法により、都市内のそ れぞれの観光スポットについて、観光客の入込み人 数を計算することが可能となり、より実際的な観光 交通計画を立てることが出来る。

最後に本研究を進めるに当たって北海道大学工学 部の佐藤蕙一助教授、高野伸栄助手には終始有益な 示唆をいただいた。また、北海道開発局土木研究所 の山中浩次氏には多大の助力をいただいた。ここに 特記して感謝の意を表わします。

参考文献

1）森地茂、『観光交通への対応』、交通工学 Vo $1.24 \quad$ No.1 1989

2 ) 田村亨、千葉博正、大炭一雄、『滞在時間に着
目した観光周遊行動の分析』、土木計画学研究・講 演集 111988

3）森地茂、田村烹、屋井鉄雄、兵藤哲朗、『観光 交通量予測モデルの事後的分析』、土木計画学研究 ・論文集 No.4 1986

4 ）溝上章志、『広域観光周遊トリップの需要予測 手法に関する一考察』、土木学会関西支部研究発表 会、1990年

5 ) Saaty, T.L、『THe Analytic Hierarchy Proce SS 、McGraw-Hill、1980

6 ）利根毫『ゲーム感覚意思決定法』、日科技 研、 1986

7 ) 宇治川正人『リゾート施設の魅力度の構造』、 オペレーションズ・リサーチ、1989年8月

8 ) 木下栄藏、佐佐木網、『階層分析による鉄道と ターミナルのイメージ構造分析』、土木計画学研究 講演集、1987年

9 ) 杉恵頼窂、『アクティビティを基本とした交通 研究への新しいアプローチ - T S U方式一』、交 通工学 Vol.19 No.2 1984

10) 高橋 清、『アクティビティ・ベイスト・アプ ローチによる過疎バス運行計画に関する研究』、土 木学会第 43 回年次学術講演会 1989

11）内田勉、河上省吾、磯部友彦、『休日における 交通・活動スケジュール決定モデルの構築』、土木 学会第 43 回年次学術講演会

12）今和泉和人、北岡大記、角知憲、『日帰りレク リエーション交通の行動モデルの作成』、土木学会 第 43 回年次学術講演会 